\title{
KULTUROWA ROLA UNIWERSYTETU W KONTEKŚCIE KRYZYSU PAŃSTWA DOBROBYTU1
}

ABSTRACT. Kościelniak Cezary, Kulturowa rola uniwersytetu w kontekście kryzysu państwa dobrobytu [Universities in the cultural conditions of the crisis of the welfare state] edited by W. Banach "Człowiek i Społeczeństwo", vol. XXXVIII, Poznań 2014, pp. 187-211, Adam Mickiewicz University Press. ISBN 978-83-232-2791-5. ISSN 0239-3271.

The paper analyses how the changes of the welfare state meets the transformation of the higher education policy in the cultural perspective. Culture plays an important role in building the concept and practice of the Western welfare state institution, also the knowledge institutions. The idea of the contemporary university is suitable to the welfare expectations. On the one hand, the universities are expected to provide mass education and minimize the differences between social strata's. On the other, after 50 years of the welfare regime in Western Europe, the state of the art universities and departments did not expand their accessibility to the students from lower social classes. What is more, in some cases, the access to is more difficult than before. The next part of the paper includes analyses of the Polish exception of the welfare state, based on the concept of the "post-grange culture" and its application to the higher education policy.

Cezary Kościelniak, Uniwersytet im. Adama Mickiewicza w Poznaniu, Wydział Nauk Społecznych, Instytut Kulturoznawstwa, Zakład Etyki Gospodarczej, ul. Szamarzewskiego 89a, 60-568 Poznań, Poland.

\section{WSTĘP}

Długofalowy kryzys państwa dobrobytu stał się uznanym powszechnie faktem, co pociąga za sobą problem, czy jego instytucje, uprawnienia i wynalazki będą mogły być nadal finansowane. Polityka społeczna, edukacyjna oraz rozwojowa opłacana przez państwo musi się zmierzyć z coraz trudniejszym zabezpieczeniem środków przeznaczonych na ten cel. Powstaje pytanie, czy państwa dobrobytu stać na utrzymanie bezpłatnej dostępności do

1 Artykuł napisany przy wsparciu Narodowego Centrum Nauki, projekt nr 1455/B/ H03/2011/40: „Innowacyjne instytucje wiedzy: Uniwersytet przedsiębiorczy w kontekście rozwoju regionalnego i wzrostu dobrobytu". 
instytucji wiedzy, w tym uniwersytetów. Czy polityka cięć spowoduje przeformułowanie kształcenia uniwersyteckiego w kierunku kształcenia i badań zorientowanych na praktyczne aplikacje? Zagadnienia te mają kontekst ekonomiczny, społeczny, polityczny, ale także kulturowy. Dostęp do praktycznie bezpłatnej edukacji staje się $\mathrm{w}$ państwie dobrobytu uprawnieniem obywatelskim, które jest postrzegane jako postęp społeczny. Niniejszy artykuł koncentruje się na kulturowych aspektach transformacji polityki szkolnictwa wyższego w kontekście państwa dobrobytu. Przyjęta perspektywa kulturoznawcza zakłada normatywno-gospodarczą analizę transformacji instytucji, w tym przypadku instytucji uniwersytetu. Autora interesuje wpływ kryzysu państwa dobrobytu na zmianę kulturowych funkcji instytucji wiedzy, a także na tworzenie się ich nowych publicznych ról.

Tekst rozpocznie naszkicowanie koncepcji ukazujących role uniwersytetu $\mathrm{w}$ państwie dobrobytu. Podobnie jak inne instytucje welfare state, także uczelnie znajdują się w kryzysie i okresie przemian². Nie jest to jednak kryzys wyłącznie finansowy, ale głębszy, kulturowy, ujawniający nowe pytania: o sens instytucji uniwersytetu, o to, na ile utrzymanie funkcji uczelni w świecie dobrobytu jest jeszcze możliwe przy stałym finansowaniu (o co coraz trudniej), ale także społecznie uznane oraz pożądane. Prezentacja państwa dobrobytu $\mathrm{w}$ kontekście roli uczelni zostanie uzupełniona uwagami o bezradności instytucji państwa $\mathrm{w}$ zaspokojeniu kulturowych aspiracji związanych z uniwersytetem.

W dalszej części artykułu naszkicowany zostanie nowy trend dotyczący modelu uczelni w państwie dobrobytu, wskazujący przejście od roli niezależnego "producenta wiedzy" do roli instytucji zaangażowanej w różne formy partycypacji $\mathrm{w}$ dostępie do wiedzy. Zmiana ta wiąże się z rosnącym uznaniem państwa partycypacyjnego, w którym dotychczasowe instytucje stają się komunikacyjnie otwarte, a ich działanie przechodzi z poziomu kontrolującego na poziom partycypacyjny, co zmienia ich optykę. Ma to zwią-

${ }^{2} \mathrm{~W}$ tekście nie zostaje podjęte zagadnienie rozumienia welfare state. $\mathrm{W}$ języku polskim funkcjonują różne określenia: państwo opiekuńcze, państwo dobrobytu, państwo liberalno-socjalistyczne. Samo rozumienie pojęcia nie jest jednoznaczne. Badacze wiążą te przemiany z aspektami ekonomicznymi i kulturowymi. Zob. I. Gough, G. Therborn, The Global Future of Welfare States, [w:] Oxford Handbook of Welfare State, eds F.G. Castles et al., Oxford University Press, Oxford 2010. Koncepcja podlegała ewolucji, por. K. Galbraith, Ekonomia a cele społeczne, przeł. W. Osiatyński, PWN, Warszawa 1979, czy J. Habermas, Kryzys państwa dobrobytu i wyczerpanie się energii utopijnych, przeł. P. Sztompka, "Colloquia Communia” 1986, nr 27. Najczęściej przyjmuje się jednak definicję państwa dobrobytu za Gøstą Esping-Andersenem. Por. G. Esping-Andersen, Trzy światy kapitalistycznego państwa dobrobytu, przeł. K. Frieske, Difin, Warszawa 2010. 
zek z nowym podziałem odpowiedzialności publicznych, gdzie obywatele domagają się większego zakresu wpływu na instytucje. Partycypacja jest tu nową formułą misji i działania uniwersytetu w państwie dobrobytu.

W ostatnim fragmencie opracowania podjęta zostanie analiza przeszkód realizacji tego zadania $\mathrm{w}$ kontekście polskim. Wychodząc od modelu folwarczno-konserwatywnej specyfiki polskiej kultury gospodarczej, przedstawimy kilka uwag dotyczących głównych przeszkód w rozwoju uczelni, w odniesieniu do obserwacji modus operandi polskiego uniwersytetu ${ }^{3}$.

\section{KULTUROZNAWSTWO GOSPODARCZE I BADANIA NAD INSTYTUCJAMI WIEDZY}

Jedną z perspektyw badawczych dla ustalenia ról uniwersytetu w państwie dobrobytu może stanowić refleksja kulturowa. Badania nad kulturą gospodarczą pokazują, że ma ona znaczenie w kształtowaniu społeczeństwa dobrobytu oraz społeczeństwa obywatelskiego. Nie ma jednego dominującego nurtu w badaniach nad wpływem kultury na praktykę ekonomiczną i instytucjonalną, zaś jej rola zostaje podkreślona w badaniach nad wpływem kultury na rozwój państw oraz przedsiębiorczości ${ }^{4}$. Kwestia ta występuje również $\mathrm{w}$ analizach i badaniach nad państwem dobrobytu i jego powiązań na przykład ze współczesną technologią czy raportach agencji międzynarodowych (OECD, ale także Banku Światowego) $)^{5}$. Znaczenie kultury jest podkreślane $\mathrm{w}$ koncepcjach przemian współczesnego społeczeństwa dobrobytu. Kultura gospodarcza staje się elementem niezbędnym w zrozumieniu czynników tła rozwoju społeczeństw, instytucji oraz wartości, określa bowiem kulturowo-instytucjonalne uwarunkowania procesów gospodarczych. Rolą kultury jest wspótregulacja zachowań gospodarczych i insty-

${ }^{3}$ Zob. J. Hryniewicz, Polityczny i kulturowy kontekst rozwoju gospodarczego, Wydawnictwo Naukowe Scholar, Warszawa 2004.

${ }^{4}$ Analizy dotyczące kulturowego tła przemian gospodarczych występują w różnych paradygmatach analiz ekonomicznych, filozoficzno-politycznych czy kulturowych. Por. D. Bell, Kulturowe sprzeczności kapitalizmu, przeł. S. Amsterdamski, Wydawnictwo Naukowe PWN, Warszawa 1998; S. Huntington, Zderzenie cywilizacji i nowy kształt tadu światowego, przeł. H. Jankowska, Muza, Warszawa 2000; A. Szirmai, The Dynamics of Socio-Economics Developments, Cambridge University Press, Cambridge 2006; A. Sen, Wolność jako rozwój, przeł. J. Łoziński, Zysk i S-ka Wydawnictwo, Poznań 1998; G. Hofstede, Cultures and Organizations, Profile Books, London 2003; A. Dylus, Globalizacja. Refleksje etyczne, Ossolineum, Wrocław 2005; P. Berger, Rewolucja kapitalistyczna, przeł. Z. Simbierowicz, Oficyna Naukowa, Warszawa 1995.

${ }^{5}$ Por. Oxford Handbook...; M. Castells, P. Himanen, Społeczeństwo informacyjne i państwo dobrobytu, przeł. M. Penkala, Wydawnictwo „Krytyki Politycznej”, Warszawa 2009. 
tucjonalnych, co zostało zauważone $\mathrm{w}$ analizach różnych odmian państwa dobrobytu, np. w fińskim społeczeństwie informacyjnym czy w koncepcjach powiązanych ze zrównoważonym rozwojem i otoczeniem społecznym ${ }^{6}$. Peter Berger podaje, że „denotacją [kultury gospodarczej - dop. C.K.] jest społeczno-kulturowy kontekst aktywności gospodarczej i funkcjonowanie instytucji gospodarczych"7. Kultura gospodarcza określa zatem nie tylko instytucje ekonomiczne, ale również instytucje w szerszym znaczeniu, kształtowane przez kontekst gospodarczy. Perspektywa kulturoznawcza oznacza skupienie się na kwestiach normatywnych ${ }^{8}$. Przedmiotem niniejszego artykułu będzie ukazanie miejsca uniwersytetów na tle kulturowych problemów związanych $\mathrm{z}$ realizacją ich roli $\mathrm{w}$ państwie dobrobytu, a więc w tym sensie jego treść będzie tyczyła się właśnie kultury gospodarczej. Przyjęte w tekście założenie wyjściowe mówi, że uczelnie są instytucjami działającymi w określonej kulturze gospodarczej, a w państwie dobrobytu odgrywają szczególną rolę kulturowo-gospodarczą, w kontekście systemów beneficjów społecznych. Jakie jest miejsce uczelni w społeczeństwie dobrobytu? Jaki wpływ mają na nie kultury gospodarcze? Niniejsze opracowanie stanowi próbę odpowiedzi na te pytania. Jednocześnie ukaże relacje pomiędzy zagadnieniem kultury gospodarczej a sferą polityki szkolnictwa wyższego. Innymi słowy, rozważania $\mathrm{z}$ zakresu „kulturoznawstwa gospodarczego" zostaną zaaplikowane do zagadnień z zakresu instytucji wiedzy oraz polityki szkolnictwa wyższego.

Badania nad kulturą w naukach społecznych pozwalają "pomóc nam $\mathrm{w}$ ulokowaniu jednostek $\mathrm{w}$ społecznym kontekście ich wartości, aspiracji i związków" ${ }^{\prime \prime}$. W tym przypadku społeczny kontekst wartości zostanie odniesiony do instytucji wiedzy - uniwersytetów - i ich kulturowych uwarunkowań. Zastosowanie metod kulturowych ma jeszcze jeden aspekt. Sama analiza ekonomiczna nie jest wystarczającą eksplanacją organizacji instytucji, w których sfera wartości, aspiracji czy idei odgrywa tak istotną rolę. Wyjaśnienie kulturowe pomoże ukazać kontekst różnych powiązań uczelni ze światem gospodarki, polityki i oczekiwaniami społecznymi od strony normatywnej.

\footnotetext{
6 Zob. P. Pavel, Breakthrough Communities, MIT Press, Cambridge, MA 2009.

${ }^{7}$ P. Berger, op. cit., s. 20, przyp. 2.

8 Zob. Culture and Welfare State, eds W. Oorschot, M. Opielka, B. Pfau-Effinger, Edward Elgar Publishing, Northampton 2008.

${ }_{9}$ Por. M. Keating, Culture in Social Science, [w:] Approaches and Methodologies in Social Science, eds D. della Porta, M. Keating, Cambridge University Press, Cambridge 2003, s. 103.
} 


\section{MIEJSCE UNIWERSYTETÓW W POLITYCE PAŃSTWA OPIEKUŃCZEGO}

Marius Busemeyer i Rita Nikolai wskazują, że edukacja stanowi trwały element polityki państwa dobrobytu: „inwestycje w edukację również kreują dobra publiczne: wyższy poziom ogólnej edukacji poszerza dobrobyt społeczeństw, a także może być istotnym instrumentem społecznym dla promocji równości szans oraz redukcji nierówności" 10 . Uniwersytet $\mathrm{w}$ społeczeństwie dobrobytu pełni jedną z zasadniczych ról w wymienionych zadaniach społecznych: promocji równości, szans, ale także - dodajmy - dostępu do awansu gospodarczego i społecznego. Rola ta została określona przede wszystkim przez czynniki ekonomiczne - głównie produktywność samych instytucji wiedzy. Marek Kwiek ukazuje ekonomiczno-instytucjonalną stronę transformacji uczelni11 ${ }^{11}$ Stawia tezę, że szkolnictwo wyższe nie podlega takiej presji zmian jak inne części systemu, głównie system emerytalny oraz opieki zdrowotnej ${ }^{12}$. Pomimo że polityka edukacyjna spadła $z$ listy priorytetów państwa opiekuńczego, to jednak ciągle pozostaje narzędziem wpływu: według Busemeyera i Nikolai pozwala ona wpłynąć na "pierwotną dystrybucję wpływów” w przeciwieństwie do innych narzędzi "kompensujących nierówności ex post"13. Innymi słowy, edukacja miałaby przeciwdziałać przyszłym nierównościom. Inną bardzo istotną stroną jest aspekt polityczny instytucji wiedzy w społeczeństwie dobrobytu. Polityczność polegałaby na zagwarantowaniu środków oraz politycznego statusu uniwersytetów, jako instytucji uznanych za stałą składową politycznego krajobrazu, a co za tym idzie, mających zagwarantowane rządowe finansowanie.

Oprócz czynników ekonomicznych usankcjonowanie wpływu instytucji wiedzy miało miejsce przede wszystkim $\mathrm{w}$ wymiarze kulturowym ${ }^{14}$. Busemeyer i Nikolai przywołują poglądy Marshalla, zgodnie z którymi „fakt realizacji obywatelskich praw społecznych koniecznie zawiera wsparcie dla

${ }^{10}$ M. Busemeyer, R. Nikolai, „Education”, [w:] Oxford Handbook..., s. 495.

11 Zob. M. Kwiek, The University and the Welfare State in Transition. Changing Public Services in Wider Context, [w:] World Yearbook of Education 2008. Geographies of Knowledge, Geometries of Power: Framing the Future of Higher Education, eds D. Epstein et al., Routledge, New York 2007, s. 32-50, oraz M. Kwiek, Transformacje uniwersytetu, Wydawnictwo Naukowe UAM, Poznań 2010.

12 M. Kwiek, The University..., s. 44, przyp. 11.

${ }_{13}$ M. Busemeyer, R. Nikolai, op. cit., s. 495, przyp. 10.

14 Wątek wymiaru kulturowego pociąga pytanie o kulturową misję uniwersytetu w globalnym świecie, zob. M. Nussbaum, Cultivating Humanity, Harvard University Press, Cambridge, MA 2007, czy też eadem, Not for Profit. Why Democracy Needs The Humanities, Princeton University Press, Princeton 2012, gdzie wskazuje się m.in. na nowe role humanistyki w świecie globalnej gospodarki i problem odpowiedzi uniwersytetu na zmiany kulturowe. 
prawa do edukacji (np. prawo do bycia wykształconym) dodanego do innych społecznych praw"15. Wynika z tego, że edukacja zostaje usankcjonowana normatywnie: prawo do edukacji, czy też patrząc od strony obywatela, „prawo do bycia wyedukowanym", jest nieodłącznym składnikiem państwa dobrobytu. Wytwarza to normatywny postulat kierowany do instytucji państwa, zachęcający do przejęcia obowiązków tworzenia instytucji edukacyjnych, jako realizację tychże praw. W państwie opiekuńczym bardzo istotna pozostaje kulturowa forma statusu uniwersytetu, jako instytucji fundującej podstawowe wymiary filozofii publicznej. Rola kulturowa uczelni ujawniła się w 2010 oraz 2011 roku poprzez masowe protesty studenckie przeciwko polityce cięć w sferze szkolnictwa wyższego ${ }^{16}$. Warto zauważyć, że protesty te łączyła ogólnoeuropejska "solidarność niezgody" na zredukowanie roli państwa w finansowaniu uniwersytetu oraz na traktowanie tego ostatniego wedle reguł czysto rynkowych. Protesty zaznaczyły zakorzenienie się szczególnego statusu uniwersytetu, którego ewentualne wyzbycie było tak samo nieakceptowalne jak kwestia poważnych cięć jego finansowania. Poniżej zostaną scharakteryzowane aspekty państwa dobrobytu oraz ról, jakie miałby odgrywać w nim uniwersytet.

Pierwszym aspektem staje się awans społeczny gwarantowany przez dostęp do wyższego wykształcenia. $W$ systemie gospodarczym dostęp do wiedzy oznacza dostęp do dobrobytu i zwiększa udział jednostek w dobrach publicznych. Społeczne ugruntowanie tej zmiany doprowadziło do przejścia z kształcenia elitarnego do kształcenia masowego. Staje się to przedmiotem długotrwałej i długofalowej zmiany, przede wszystkim zwrotem przedsiębiorczym w szkolnictwie wyższym rozpoczętym w Stanach Zjednoczonych, ale bardzo szybko zaadaptowanym w Europie. Zmianę tę symbolizuje książka Clarka Kerra The Uses of the University17. Jej elementem w Stanach Zjednoczonych było powstanie nowych narzędzi pomocowych, takich jak pożyczki studenckie czy system stypendiów federalnych dynamizujących masowe kształcenie. Umasowienie kształcenia występuje jednak równocześnie ze „zwrotem przedsiębiorczym”, oznaczającym nie tylko

${ }^{15}$ M. Busemeyer, R. Nikolai, op. cit., s. 496.

${ }^{16}$ Kwestie protestów studenckich omówiono w tekstach A. Abbas, C. Kościelniaka i A. Magnier, [w:] Wolność, równość, uniwersytet, red. C. Kościelniak, J. Makowski, Instytut Obywatelski, Warszawa 2011. Warto zauważyć, że środowisko akademickie stało się zinstytucjonalizowaną grupą nacisku politycznego, co w sytuacjach napięć wyraża się w buncie, szczególnie w krajach transformacji, np. w Pekinie w 1989 czy w Egipcie w 2012 roku. W świecie zachodnim protesty wiązały się jednak ze zmianami w polityce szkolnictwa wyższego, zob. M. Mariel, A. Lemonik, Student Activism and Curricular Change in Higher Education, Ashgate Publishing, Farnham 2011.

${ }_{17}$ C. Kerr, The Uses of the University, Harvard University Press, Cambridge, MA 2001. 
komercjalizację badań i płynących z tego globalnych konsekwencji dla przemysłu, ale także zmianę $\mathrm{w}$ polityce edukacyjnej: zostaje ona przyporządkowana szybkiemu wejściu absolwentów na rynek, dodajmy, absolwentów zawodowo przygotowanych. Parametrem określającym dostępność jest m.in. stopień scholaryzacji, który w krajach zachodnich $\mathrm{w}$ ostatnich czterdziestu latach wzrósł o kilkaset procent, a obecnie w krajach OECD wynosi ponad 35\% (w grupie wiekowej 24-35 lat) ${ }^{18}$. Rewolucja dostępności do uczelni na Zachodzie miała swoje konsekwencje instytucjonalne: w ciągu kilkudziesięciu lat powstało wiele nowych uczelni ukierunkowanych na kształcenie masowe i mających na celu zrównoważenie szans. Wiedza stała się czynnikiem zmiany kulturowej: dostęp nie tyle do wiedzy, co do instytucji wiedzy staje się przywilejem, momentem zmiany kulturowej rozpoczynającej się w latach sześćdziesiątych ubiegłego wieku. Ponownie, protesty w 2010 roku odwołują się do zmniejszenia dostępności i są reakcją na odbieranie społecznie zagwarantowanych praw. Dostępność w tym modelu staje się conditio sine qua non awansu społecznego, wejścia na rynek lepiej opłacanej, zamożnej klasy średniej oraz korzystania z kapitału społecznego przynależnego tej klasie. Społeczeństwa przyswoiły wiedzę, że zarobki osób z wyższym wykształceniem przewyższają zarobki pracowników z niższym, a wykształcenie staje się drogą do awansu społecznego. Świadomość tego faktu w latach dziewięćdziesiątych ujawniła się w krajach postkomunistycznych, gdzie nastąpił boom edukacyjny.

Kolejnym powiązaniem uniwersytetu z państwem dobrobytu są wydatki na szkolnictwo wyższe. Państwo opiekuńcze przyjmuje na siebie odpowiedzialność za finansowanie edukacji, przynajmniej jego większej części. W krajach Unii Europejskiej standardem staje się poziom wydatków na tę sferę zbliżony do 1,5\% PKB. W państwie opiekuńczym sfera wydatków na edukację powiązana jest $\mathrm{z}$ jej kontrolą przez państwo, a co za tym idzie, z publicznym uzgodnieniem agendy nauczania. Warto jednak zauważyć, że nawet w krajach skandynawskich - gdzie uczelnie mogą cieszyć się znaczną i nienaruszalną pozycją $\mathrm{w}$ strukturach finansowania publicznego - stosuje się mechanizmy wolnorynkowe. Przykładem jest Finlandia. Otrzymanie grantu z publicznych środków wymaga uzyskania wsparcia z pieniędzy przedsiębiorstw, co z góry kreuje komercyjny charakter wiedzy ${ }^{19}$. Jednakże gros wydatków pochodzi z budżetu państwa.

18 Zob. Education at Glance, OECD, Paris 2011. Wzrost dostępności do edukacji staje się jednym z najważniejszych celów rozwojowych państw.

${ }_{19}$ Działanie systemu finansowania fińskich instytucji wiedzy, zob. O. Toivanen, Innovation Policy, Entrepreneurship and Development: A Finnish View, [w:] Entrepreneurship, Innovation, and Economic Development, eds A. Szirmai et al., Oxford University Press, Oxford 2011. 
Istotną rolą uczelni w welfare state jest zbliżenie studiów i ich efektów do rynków pracy zarówno poprzez sterowanie rządowymi i ponadnarodowymi funduszami, jak i zmianę $\mathrm{w}$ samych uczelniach $\mathrm{w}$ postaci przeformułowania programów studiów oraz programów badawczych w kierunku potrzeb gospodarczych i aplikacji. Taka zmiana jest priorytetem Komisji Europejskiej $\mathrm{w}$ obecnym okresie finansowym ${ }^{20}$. Ponadnarodowa agenda w tym zakresie została wzmocniona przez politykę Unii Europejskiej (głównie Strategię lizbońską). W perspektywie finansowej Unii Europejskiej na lata 2004-2013 taka optyka stała się dominująca. Warto zauważyć, że ta perspektywa została zaakceptowana przez większość państw UE, a także państw stowarzyszonych ze Wspólnotą. Postuluje się, aby uniwersytety były bliżej rynków pracy poprzez kompetencje i umiejętności społeczne. Taki był wydźwięk wprowadzania Krajowych Ram Kwalifikacji oraz projektów wspierania mobilności (głównie ERASMUS oraz jego edycja od roku 2014 ERASMUS+) ${ }^{21}$.

Uniwersytet $\mathrm{w}$ państwie dobrobytu jest powiązany z funkcją partycypacyjną. Do opisu tej kategorii Roland Scholz używa terminu transdyscyplinarności22. Rozumie pod nim działania mające na celu organizację procesów społecznych, w których aktorami zmiany są podejmujący decyzje publiczne, wspólnota badaczy oraz wspólnota lokalna. Tym samym działalność naukowa zostaje ukierunkowana na zaangażowanie $\mathrm{w}$ partycypację. $\mathrm{Z}$ jednej strony polega to na tworzeniu nowych ról w kontekstach społecznych, $\mathrm{z}$ drugiej jest to efekt urzeczywistnienia nowych funkcji instytucji wiedzy związanych z państwem dobrobytu. Scholz łączy funkcję partycypacyjną z funkcją społeczno-środowiskową ${ }^{23}$. Według niego uczelnie zaangażowane są $\mathrm{w}$ dwa typy partycypacji: pierwsza wiąże się z funkcją konsultacyjną i zostaje zaangażowana na poziomie decyzji politycznych. Drugi typ ma charakter wspólnototwórczy i polega na włączaniu lokalnych interesariuszy w agendę badawczą uniwersytetów. $W$ tym momencie pojawia się również nowy ośrodek wartości dla uczelni: zaangażowanie w lokalne środowisko. W dwóch

${ }^{20}$ C. Kościelniak, Polityka szkolnictwa wyższego w Unii Europejskiej, [w:] Polityka Unii Europejskiej, red. E. Małuszyńska (w druku).

${ }_{21}$ Zob. C. Kościelniak, Unijne wyzwania polskiego szkolnictwa wyższego, [w:] Polska w Unii Europejskiej. Bilans dekady, red. F. Tereszkiewicz, Kancelaria Prezydenta, Warszawa 2013. Komisja Europejska traktuje program ERASMUS jako narzędzie pomocne w nabywaniu nowych kompetencji przez studentów. W taki sposób program ten odbierają także środowiska pracodawców, zob. Pierwsze kroki na rynku pracy. Międzynarodowe badania absolwentów, raport firmy Deloitte, Warszawa 2013.

22 R. Scholz, Environmental Literacy in Science and Society, Cambridge University Press, Cambridge 2012, s. 373-379.

23 Ibidem, s. 378. 
przypadkach można mówić o środowiskowej funkcji uniwersytetu. Zaangażowanie może wyrażać się między innymi implementacją zasad zrównoważonego rozwoju $\mathrm{w}$ edukację i infrastrukturę uczelni ${ }^{24}$. Zrównoważony rozwój wpisuje się w politykę państwa dobrobytu, jego celem jest podnoszenie jakości życia oraz ochrony środowiska naturalnego i społecznego. Partycypacyjna funkcja uniwersytetu wpisuje się $w$ politykę państwa dobrobytu: wynika ona $\mathrm{z}$ odpowiedzialności za wspólnoty oraz potencjalnych $u \dot{z} y t k o w-$ ników wiedzy.

\section{ROLE UNIWERSYTETU W PAŃSTWIE OPIEKUŃCZYM}

Prawo do powszechnej i bezpłatnej edukacji jako jedno z założeń państwa dobrobytu głęboko wpłynęło na politykę szkolnictwa wyższego, przede wszystkim w krajach Europy Zachodniej. W idealnym założeniu dobrobyt staje się synonimem pewności dostępu: już nie otwiera, ale zapewnia dostęp do instytucji wiedzy, a przez to gwarantuje awans ekonomiczny i społeczny. Oczywiście, taka sytuacja ma miejsce również w państwach o neoliberalnym reżimie gospodarczym, różnica polega zaś na tym, że w państwie opiekuńczym źródłem dobrobytu jest redystrybucja dóbr publicznych, a nie kapitał poszczególnych jednostek. Podejście to przynosi poważne konsekwencje zarówno poznawcze, jak i etyczne. Poznawcze oznaczają przeobrażenie wiedzy w nową formułę, przeobrażenie jej w aplikacje o charakterze zawodowym. Konsekwencje etyczne są natomiast takie: autotelicznie pojmowana "prawda” jako kontemplacyjny cel poznawczy zostaje zastąpiona funkcja utylitarna - poznanie zostaje ukierunkowane na postęp cywilizacyjny: ekonomiczny oraz technologiczny. Źródłem tej presji staje się rynek, który monopolizuje poszczególne obszary życia, w tym także edukacji. Zmiana ta silnie wpłynęła na instytucje szkolnictwa wyższego, które zaimplementowały zmianę swego modelu, nazwaną przez Clarka Kerra „multiuniwersytetem”, a w późniejszym okresie przez Burtona Clarka „uniwersytetem przedsiębiorczym" 25 . Konsekwencją tej zmiany jest marginalizacja badań i wydziałów niewpisujących się w utylitarny model produkcji wiedzy, nienastawionych na aplikacje, nieoferujących powiązań z rynkiem oraz nieproponujących kształcenia do prominentnych zawodów. Kolejną konse-

${ }^{24}$ Zob. World in Transition: Sustainability Perspectives for Higher Education, eds M. Adomssent, A. Beringer, M. Barth, VAS Verlag, Frankfurt 2013; C. Kościelniak, R. Roemer, Sustainable Development as a Part of the "Third Mission" of the Universities, "Safety of Technogenic Environment" 2013, no. 4, Riga.

25 Zob. B. Clark, Creating Entrepreneurial University, Pergamon, Oxford 1998. 
kwencją jest biurokratyzacja uniwersytetu oraz przekształcenie go w instytucję działającą na wzór przedsiębiorstwa. "Zwrot przedsiębiorczy” uniwersytetu wywołuje głosy krytyki. Tadeusz Sławek powiada o „moralnym dryfie" instytucji, „władzy biurokracji” oraz dezintegracji instytucji uniwersytetu i jego tradycyjnej misji26.

Bardzo istotna zmiana ma miejsce $\mathrm{w}$ misji, jaką jest kształcenie. W klasycznym wydaniu ideałem wiedzy jest intelektualne wyposażenie absolwenta $\mathrm{w}$ wiedzę, ale także $\mathrm{w}$ etos, odpowiedzialność za jej użycie. $\mathrm{W}$ tym sensie wiedza oznaczała nierozerwalne współdziałanie teorii z praktyką ${ }^{27}$. Model ten można odnaleźć $\mathrm{w}$ literaturze określającej role uniwersytetu, m.in. w książkach Idea uniwersytetu Newmana, Mission of the University Gasseta czy polskim traktacie Kazimierza Twardowskiego $O$ dostojeństwie uniwersytetu $^{28}$. Sytuacja kulturowa uniwersytetu zmienia się fundamentalnie po zwrocie $\mathrm{w}$ polityce publicznej $\mathrm{w}$ kierunku welfare state, kiedy to usankcjonowano zupełnie nowy model użycia wiedzy, a przez to siłą rzeczy zepchnięto dyskurs "mądrościowy" na margines, uznając go za bezproduktywny ${ }^{29}$. Nowe użycie wiedzy, jako bramy do dobrobytu, dokonało się na poziomie funkcjonalnym, jednakże pociągnęło też zmianę na poziomie instytucji uniwersytetów, dogłębnie przeobrażając system na poziomie aksjologicznym, co spowodowało zmianę społecznego znaczenia uniwersytetu. Tym samym wiedza stała się transmiterem awansu społecznego, a uniwersytet instytucją odpowiadającą na potrzeby badawcze i edukacyjne przyczyniające się do powiększenia puli dobrobytu. $W$ tym przypadku pojawia się zupełnie nowa formuła relacji między studentem a uniwersytetem, bardziej przypominająca sytuację petenta instytucji socjalnej, który otrzymuje przydział należnego mu dobra publicznego. W tym sensie instytucje edukacyjne działają jak pozostałe wynalazki socjalne na masową skalę: służba zdrowia, państwowa opieka nad małym dzieckiem czy system emerytalny.

Zmiana użycia instytucji wiedzy doprowadziła także do zmiany kulturowej wtasności wiedzy. Wiedza - zarówno kontrola nad nią, produkcja, jak i zastosowanie - nie jest już domeną samych uczonych, ale studentów, apli-

26 T. Sławek, Autonomia, integralność, uniwersytet, "Anthropos” 2012, vol. 18/19, s. 12-30.

${ }^{27}$ Por. T. Sławek, Autonomia, dtug, ksztatcenie, [w:] Wolność, równość..., s. 193, przyp. 12.

28 Por. J.H. Newman, Idea uniwersytetu, przeł. P. Mroczkowski, PWN, Warszawa 1990; O. y Gasset, Mission of the University, Princeton University Press, Princeton 2009; K. Twardowski, O dostojeństwie uniwersytetu, reprint z 1931 roku, Wydawnictwo Naukowe UAM, Poznań 2011.

29 Należy zaznaczyć, że utylitarno-funkcjonalny model użycia wiedzy powstaje pod wpływem presji rynkowej: oznacza to, że ma on miejsce zarówno w państwach o charakterze neoliberalnym, jak i państwie dobrobytu. Powstaje pytanie o różnice między tymi reżimami w kontekście ich wpływu na marginalizację nieutylitarnych dyscyplin wiedzy. 
katorów patentowych, wspólnot czy innych zewnętrznych interesariuszy ${ }^{30}$. Spowodowało to powstanie zupełnie nowego kierunku, jakim była partycypacyjna koncepcja wiedzy. Rewolucja informatyczna i powstanie społeczeństwa informatycznego - jak to nazywają Castells i Himanen - jako kolejnej odsłony państwa dobrobytu, przyczyniła się do partycypacyjnego rozwoju wiedzy. Nie jest to jedynie zmiana techniczna czy organizacyjna. Jest to głęboka przemiana kulturowa instytucji publicznych, w tym także instytucji kultury oraz instytucji wiedzy. Wojciechowski podsumowuje te przemiany jako pragmatyzację kultury - włączając w jej skład także naukę: „Wcześniejsze, regulatywne bądź radykalnie modernistyczne [...] funkcje kultury symbolicznej wobec ustroju gospodarczego [...] wypierane są przez kulturę zajmującą coraz szerszy segment neoliberalnego rynku [...], a pewne zasady i wzory (m.in. tzw. kreatywność i innowacyjność) wchłaniane są [...] w zasady funkcjonowania kapitalistycznego przedsiębiorstwa" ${ }^{\prime \prime}$. Dalej autor wskazuje przeniesienie kultury na „dobro” $\mathrm{i}$ „zasób”, co jest zgodne z logiką państwa dobrobytu, gdzie wiedza staje się zasobem ${ }^{32}$. Aktualna odsłona uniwersytetu $\mathrm{w}$ państwie opiekuńczym również ma charakter partycypacyjny: społeczeństwo już nie tyle wykorzystuje instytucje wiedzy, ile aktywnie włącza je w różne praktyki gospodarcze i społeczne. Tym samym spełnia oczekiwanie włączenia. Wydaje się jednak, że nowa formuła uniwersytetu wygenerowała nowe wartości: jest to uniwersytet bliski społeczności, bardziej odpowiedzialny za swoje otoczenie, innymi słowy: „środowiskowo partycypujący".

\section{KRYZYS PAŃSTWA DOBROBYTU JAKO KRYZYS UNIWERSYTETU}

Powyższe rozważania domagają się jednak odpowiedzi na pytanie, czy model „edukacji dobrobytu” można jeszcze utrzymać. Kryzys państwa dobrobytu szczególnie dotyka uniwersytetu. W paradygmacie instytucjonalnym Marek Kwiek nazywa ten proces „renegocjacją kontraktu społecznego”. Jednakże, jak sam konkluduje, uczelnie muszą zmagać się z warunkami ciągłych przemian, a obecnie „Wiele decyzji specyficznych dla danych krajów oraz kultury zostanie podjętych zarówno przez policy makerów, jak

\footnotetext{
30 Rozwinięciem tego wątku powinno być zaprezentowanie dyskusji dotyczącej własności intelektualnej.

31 S. Wojciechowski, Instytucje kultury w Polsce na tle przemian kultury w latach 1989-2009. Globalizm, lokalność, kryzys, [w:] Instytucje kultury w czasach kryzysu, red. P. Kieliszewski i in., Bogucki Wydawnictwo Naukowe, Poznań 2009, s. 16.

32 Ibidem.
} 
i akademickie instytucje, a ich efekt jest ciągle bardzo trudny do przewidzenia"33. Niepewność wiąże się z kryzysem ekonomicznym - jest to niepewność ciągłości finansowania. Modelowe państwo dobrobytu staje się coraz bardziej odległą przeszłością pozbawiającą złudzeń co do możliwości utrzymania ekonomicznego statusu uczelni. W wymiarze szkolnictwa wyższego mamy do czynienia $\mathrm{z}$ kryzysem $\mathrm{w}$ niemal każdej $\mathrm{z}$ wymienionych w poprzednim paragrafie dziedzin.

Najbardziej zagrożona wydaje się kwestia sprawiedliwego dostępu do instytucji edukacji wyższej. Kryzys ten widać na przykładzie kraju, który był pionierem zmian, tj. Francji. Po rewoltach społecznych $w$ latach sześćdziesiątych XX wieku jednym z głównych zadań francuskiej polityki szkolnictwa wyższego było zapewnienie równego dostępu do uczelni. Gaële Goastellec pokazuje, że akcje afirmatywne i próba równościowego potraktowania studentów okazała się eksperymentem, który nie spowodował zmniejszenia różnic w dostępie do wiedzy ${ }^{34}$. Do najbardziej elitarnych i dających karierę w instytucjach rządowych uczelni w przeważającej większości dostają się dzieci osób, które takie uczelnie wcześniej już ukończyły; grupy „niereprezentowane” właściwie w tych uczelniach nie zwiększyły swego udziału. Goastellec nazywa wręcz Grandes Écoles „kamuflażem odtwarzania struktury społecznej". Dostępność jest również problemem polskim. Z jednej strony od 1989 roku wzrosła ona z kilku procent do średniej OECD. Z drugiej - pojawia się dylemat, czy ilość przekłada się na jakość edukacji.

W kontekście polskiego wzrostu Marek Kwiek komentuje ten dylemat następująco: „[...] koszty tego rozwoju domagają się ostrożnej oceny: brak kontroli jakości oraz problemy z finansowaniem [...] oraz konflikt pomiędzy ilościowym rozwojem/ekspansją systemu a standardami jakości"35. Inną sprawą pozostaje przełożenie wyniku edukacji na wejście do umożliwiającej dobrobyt kariery. W Polsce taką renomę - można ją mierzyć rankingiem pracodawców - ma zaledwie kilkanaście uczelni ${ }^{36}$. Problem z dostępem do uczelni wzrósł również w Stanach Zjednoczonych, i to za rządów liberałów. Pula środków na stypendia rządowe spadła, co spowodowało obciążenie najuboższych wzrostem czesnego w roku 2014. Przykłady amerykańskie

33 M. Kwiek, The University..., s. 45.

${ }^{4}$ G. Goastellec, Wolność dostępu do uniwersytetów. Gwarancja nierówności?, [w:] Wolność, równość..., s. 193, przyp. 12.

35 M. Kwiek, Accessibility and Equity, Market Forces and Entrepreneurship: Developments in Higher Education in Central and Eastern Europe, "Journal of the Programme on Institutional Management in Higher Education" 2008, vol. 20, OECD, Paris, s. 92.

36 Zob. ranking pracodawców magazynu „Perspektywy” pt. Prestiż wśród pracodawców: http:/ / www.perspektywy.pl/portal/index.php?option=com_content\&view=article\&id=713: prestiz-pracodawcow\&catid=90\&Itemid=230 [dostęp: 17.09.2014]. 
może nie są tak istotne, gdyż trudno mówić tam o państwie dobrobytu $\mathrm{w}$ stylu europejskim (świadomie pomijamy w tekście modele państwa dobrobytu), ale niewątpliwie mamy do czynienia z trendem przeciwnym doktrynie traktującej edukację jako prawo (right). To zaś było hasłem wyborczym prezydenta Obamy na drugą kadencję.

Przykład ze Stanów Zjednoczonych jest istotny, wskazuje bowiem na problem kurczenia się dostępu do instytucji wiedzy jako problem globalny. Nie inaczej sprawa wygląda z cięciami finansowymi. O ile wydatki na służbę zdrowia oraz emerytury nie zmalały, o tyle szkolnictwo wyższe w Europie zostało środków w jakiejś mierze pozbawione. Dotkliwe redukcje budżetów nastąpiły między innymi we Włoszech, Wielkiej Brytanii, Portugalii i Grecji. Nie lepiej jednak było w Polsce; warto zauważyć, że w naszym kraju PKB na szkolnictwo wyższe nie wzrastało w ostatniej dekadzie, a w porównaniu z rokiem 2005 zmniejszyło się o 0,2\% PKB. Nie widać też specjalnej zmiany w oczekiwanej efektywności edukacyjnej uczelni. Szczególnie trudne pozostaje zagadnienie przejścia absolwentów z uczelni na rynki pracy: bezrobocie wśród młodych ludzi nie zmniejsza się, a w roku 2013 nawet nieznacznie pogłębiło się w krajach "starej” Unii Europejskiej. Widać wyraźnie, że nakłady na dostosowanie profili kształcenia do miejsc pracy nie przyniosły pożądanych efektów.

Podobnie problematyczne pozostaje tworzenie instytucji wiedzy w miejscach o niskim potencjale gospodarczym, ekonomicznym i kulturowym, czyli na peryferiach gospodarczych i kulturowych. Lokalizacje nowych uczelni wypływają (1) z polityki poszerzenia dostępności do instytucji wiedzy dla osób z grup niereprezentowanych, (2) z polityki podnoszenia potencjałów regionów rozwijających się. Bywa jednak, że wybór lokalizacji nowych uczelni nie jest zgodny $\mathrm{z}$ racjonalnością rozwojową regionów, a tworzenie kultury akademickiej na peryferiach napotyka wiele poważnych przeszkód strukturalnych ${ }^{37}$. Przykładem są inwestycje w wyższe szkoły zawodowe. Do chwili obecnej nie stwierdzono, aby lokalizacja wyższych szkół zawodowych - w Niemczech i w Polsce - mających przyczynić się do usprawnienia kształcenia zawodowego $\mathrm{w}$ regionie przyniosła $\mathrm{w}$ skali tych krajów pożądane efekty, jakkolwiek w kilku ośrodkach takie efekty pojawiły się. W większości przypadków „uczelnie peryferyjne” - nie tylko zawodowe -

37 Kwestie przeszkód strukturalno-rozwojowych szkolnictwa wyższego w Europie Centralnej, por. C. Kościelniak, The Context of the "Third Mission" in the "Peripherial Universities". A Case Study of the "Cross-border" University, [w:] Thinking about Provincialism in Thinking, eds K. Brzechczyn, K. Paprzycka, „Poznan Studies in the Philosophy of Science and the Humanities" 2012, vol. 100, Rodopi, Amsterdam-New York, s. 197-215; Z. Gal, P. Ptacek, The Role of Mid-Range Universities in Knowledge Transfer in Non-Metropolitan Regions in Central Eastern Europe, „European Planning Studies” 2011, vol. 19, iss. 9, s. 1669-1690. 
skazane są na końcowe pozycje w rankingach oraz dostępie do badań ${ }^{38}$. Temat relacji ośrodków wiedzy w kontekście geograficznym wykracza poza ramy niniejszego tekstu, przy czym istniejące badania pozwalają na stwierdzenie, że potencjał akademicki zależy od potencjału regionów ${ }^{39}$. W tej sytuacji można zapytać, czy polityka szkolnictwa wyższego należy jeszcze do doktryny społeczeństwa dobrobytu. A jeśli nominalnie tak, to czy w najbliższej perspektywie finansowej $\mathrm{w}$ państwach Europy oraz we Wspólnocie Europejskiej uda się przywrócić jej priorytetowy charakter. Obecnie taki powrót nie wydaje się szybko możliwy.

Powstaje jednak inne zasadne pytanie: czy uniwersytet $\mathrm{w}$ państwie dobrobytu wpisuje się w politykę generowania dobrobytu. Czy dostępność do uczelni rzeczywiście doprowadziła do dostępu do zasobów i dobrobytu obywateli (vide bezrobocie wśród absolwentów)? Czy lokowanie nowych uczelni w regionach peryferyjnych - w celu zwiększenia szans mieszkańców lokalnych wspólnot - polepszyło jakość tych regionów i ich mieszkańców? Czy zamierzenie zrównoważonego wzrostu nakładów na edukację wyższą priorytet państwa dobrobytu - poza krótkotrwałym „złotym okresem” lat siedemdziesiątych i osiemdziesiątych - będzie jeszcze w jakikolwiek sposób możliwe do utrzymania? Czy edukacja wytrzyma konkurencję z coraz bardziej kosztochłonnym systemem opieki emerytalnej i zdrowotnej, który z każdą dekadą staje się coraz mniej wydajny (biorąc pod uwagę wzrost kosztów technologii medycznych oraz - co zdaje się czynnikiem najważniejszym - zapaść demograficzną Europy)? Ta ostatnia kwestia adresowana jest do krajów europejskich, w tym także Polski. Zofia Szweda-Lewandowska wskazała na przyśpieszenie procesów starzenia się w krajach postkomunistycznych: „Tempo spadku tego współczynnika [starzenia - dop. C.K.] wskazuje, że Polska i inne kraje postkomunistyczne w ciągu 10 lat przeszły przez proces, który w starych krajach Unii trwał 40 lat" 40 . Innymi słowy, hojne państwo dobrobytu zostanie zastąpione państwem uwikłanym w coraz większe koszty i zobowiązania. Widać to choćby w Polsce czy w Niemczech, gdzie po upadku komunizmu powstało wiele nowych fundowanych przez państwo instytucji szkolnictwa wyższego, które przy malejącym rozwoju demograficznym stają się zbędne. $W$ obecnych realiach demograficznych nie sposób sfinansować edukacji każdego szczebla ze środków

38 Zob. raport NCN, Statystyki konkursów, NCN, Kraków 2013.

39 Zob. A. Olechnicka, Potencjat nauki a innowacyjność regionów, Wydawnictwo Naukowe Scholar, Warszawa 2012.

40 Z. Szweda-Lewandowska, Procesy ludnościowe w Polsce - następstwa przystapienia do Unii Europejskiej, [w:] Polska w Unii Europejskiej. Bilans dekady, red. F. Tereszkiewicz, Kancelaria Prezydenta, Warszawa 2013, s. 105. 
publicznych. Wszystkie te kwestie można sprowadzić do ogólnego pytania, czy powrót do państwa dobrobytu, z centralną pozycją instytucji wiedzy, może w najbliższej przyszłości jeszcze nastąpić. Przyglądając się polityce reglamentacji dostępu do dóbr socjalnych $\mathrm{w}$ Europie, presji płynącej ze zmian demograficznych, nieustającego kryzysu finansowego oraz coraz mniej wydolnej europejskiej biurokracji, można mówić nie tylko o kryzysie tego modelu, lecz wręcz o powrocie do społeczeństwa liberalnego - co najwyraźniej uwidacznia się na poziomie edukacji. W sferze szkolnictwa wyższego przejawia się to między innymi powrotem do polityki odpłatności za kształcenie w Europie rozstającej się z mitem powszechnej dostępności i afirmacją grup nieuprzywilejowanych oraz zmianą kulturową, gdzie edukacja na powrót staje się obowiązkiem ekonomicznym raczej rodzin - płacących za edukację ze swoich środków, aniżeli państwa - dostarczającego obywatelom kształcenia ze środków publicznych. Widać to wyraźnie na przykładzie polityki podnoszenia czesnego w uczelniach krajów Unii Europejskiej. W Polsce takim znakiem jest podnoszenie jakości kształcenia w najlepszych uczelniach prywatnych - ukierunkowanych na zaawansowane kształcenie zawodowe - oraz przyrost liczby studentów w tych uczelniach pomimo czesnego ${ }^{41}$. W polskiej mentalności społecznej edukacja trzeciego stopnia powoli staje się sprawą prywatną: stąd też nie wzbudza protestów społecznych kwestia odpłatności za studia. Innymi słowy, kosztami społecznymi, w tym także kosztami kształcenia, zostaną obciążeni obywatele; jest też wysoce prawdopodobne, że utrzymywanie systemu publicznego szkolnictwa wyższego w Europie może stać się kulturowo coraz mniej akceptowalne.

Innym zagadnieniem pozostaje kwestia zrównoważonego rozwoju. W chwili obecnej trudno przewidzieć, czy partycypacyjna funkcja wiedzy przełoży się na pożądany mechanizm zwiększenia produkcyjności i wchłaniania absolwentów na rynek pracy ${ }^{42}$. Powstaje zatem pytanie, czy przenie-

41 Przykładem są wysoko rankingowane uczelnie niepubliczne, jak np. SWPS czy Collegium Civitas. Uruchomiły one po 2004 roku (data wejścia Polski do Unii Europejskiej) ekskluzywne programy studiów, np. na SWPS w Poznaniu powstał wydział designu, a na CC programy dla policy makerów. W obu przypadkach czesne jest wysokie, pomimo to uczelnie notują zainteresowanie studentów, także zza granicy. Innym przykładem może być uczelnia Vistula, która uruchomiła anglojęzyczne programy dla studentów zza granicy, jednocześnie utrzymując egzaminy wstępne. Kwestia nie ogranicza się do instytucji niepublicznych, także uczelnie publiczne utrzymują kosztowne, komercyjne programy studiów, głównie MBA.

42 Obecnie trudno przewidzieć skutki tej zmiany. Jednakże skutki pewnych aspektów polityki zrównoważonego rozwoju już przyniosły negatywne efekty społeczne, np. przeludnienie i promocję mniejszej dzietności. Realizacja postulatu zmniejszenia dzietności w Europie w tym w Polsce - doprowadziła do wielopokoleniowego kryzysu, podczas gdy kraje „przeludnione", jak np. Brazylia czy Indie, notują rozwój gospodarczy. 
sienie zrównoważonego rozwoju na model sustainable university pociągnie za sobą pożądany efekt ekonomiczny. Podobna kwestia dotyczy partycypacyjności. Czy podzielenie się mechanizmami tworzenia wiedzy z aktorami zewnętrznymi rzeczywiście okaże się skuteczne i bardziej pobudzające uniwersytety do działania? Zapotrzebowanie na zaawansowaną wiedzę musi odpowiadać warunkom infrastrukturalnym; wydaje się, że wspólnoty tylko do pewnego stopnia mogą ją wykorzystać.

Kolejnym zagadnieniem jest kierunek zmian politycznych $\mathrm{w}$ polityce uczelnianej płynący z Komisji Europejskiej. Istnieje ryzyko, że kryzys uniwersytetu w państwie dobrobytu w Unii Europejskiej powiększy się. W nowej perspektywie finansowej programy mobilności, szczególnie ERASMUS+, obejmują kraje Partnerstwa Wschodniego oraz Południowego. Oznacza to wzrost napływu potencjalnych beneficjentów, którzy będą dążyli do długoterminowego pobytu w krajach UE. Efektem może stać się zjawisko „obrony rynku”, jeszcze większe kurczenie się oferty socjalnej państw UE oraz polityka reglamentacji dostępu do instytucji wiedzy. Zapełnienie uniwersytetów studentami zza granicy jest mitem, gdyż mało które państwo pozwala sobie na finansowanie edukacji obywateli obcych państw. Trudno jednak powiedzieć, czy zmiany te oznaczałyby powrót do tradycyjnego modelu uniwersytetu, z jego elitarną i zdystansowaną - czy, jak to ujął Twardowski, dostojną - wobec świata pozycją. W społeczeństwie informacyjnym nie będzie już miejsca na uznanie autonomicznych ekspertów ani wiedzy, która byłaby oderwana od kontekstu społecznego lub zdobyłaby szczególnie uprzywilejowaną pozycję $\mathrm{w}$ egalitarnym społeczeństwie. $\mathrm{W}$ tym znaczeniu - powtarzając za cytowanym wyżej Markiem Kwiekiem - nie sposób wskazać trajektorii rozwoju uniwersytetu przyszłości.

\section{POLSKIE KULTUROWE OGRANICZENIA PAŃSTWA DOBROBYTU}

W ostatniej części tekstu spróbujemy odnieść się do polskiego kontekstu państwa dobrobytu i jego związków z uniwersytetem. W Polsce model ten jeśli chodzi o edukację - jest w założeniu politycznym realizowany w następujący sposób: państwo zapewnia dostęp do kształcenia, a konstytucja expressis verbis traktuje edukację jako bezpłatną. Polska nie jest ani państwem opiekuńczym - biorąc pod uwagę chroniczne niedofinansowanie, ani też liberalnym - ze względu na pomijanie reguł rynkowej konkurencji w organizacjach instytucji publicznych. Oprócz problemów dotyczących sfery gospodarczej pojawiają się jednak problemy kulturowe. Podejmując próbę ich 
zdefiniowania, będziemy się posługiwać konstrukcją Janusza Hryniewicza i jego koncepcją organizacji polskiej gospodarki ${ }^{43}$.

Przedstawienie problematyki uczelni $\mathrm{w}$ kontekście polskiej polityki dobrobytu wymaga skrótowego wprowadzenia w specyfikę naszego kraju określoną jako model „kultury gospodarczej folwarcznej” i jej kulturowe konsekwencje. Hryniewicz opisuje transformacje polskiej kultury gospodarczej, wskazując na szczególną rolę modelu folwarków. Folwarki - autonomiczne gospodarstwa produkcji żywności - stają się głównym narzędziem wytwarzania dóbr w państwach Europy Środkowej i Wschodniej, głównie I Rzeczypospolitej. Relacje społeczne opierały się w nich nie tylko na realizacji produkcji, ale także na ingerencji $\mathrm{w}$ życie prywatne zatrudnionych na folwarkach ludzi. Właściciele folwarków byli pracodawcami, ale także opiekowali się wasalnymi rodzinami, de facto wpływali na ich życie osobiste i społeczne, wyznaczali role społeczne itp. Folwarki wytworzyły specyficzną kulturę zachowań, która $\mathrm{w}$ pewnym stopniu przetrwała do dziś. Jest ona źródłem wielu cech kulturowo ugruntowanych w systemie organizacji, np. w bierności czy „preferencjach krewniaczych” w pracy. System folwarczny stał się anachroniczny w wiekach XIX i XX wobec nowych kultur organizacyjnych, szczególnie powiązanych z kształtowaniem się klasy mieszczańskiej, a następnie rewolucją przemysłową na Zachodzie ${ }^{44}$. Ugruntowanie się wzoru mentalności folwarcznej w świadomości społecznej stało się przeszkodą w rozwoju, a obecność „postfolwarcznej kultury” jest współcześnie silnie zakorzeniona. Za Hryniewiczem można wymienić najbardziej charakterystyczne cechy świadomości folwarcznej, do których należą ${ }^{45}$ :

- preferencja związków krewniaczych i postaw wspólnotowych ponad realizację celów organizacji;

- posłuszne i wierne wykonywanie pracy, nastawienie się na dyspozycje kierownicze z nikłym stopniem własnej inicjatywności;

- homogeniczność środowiska pracy związana z niskim stopniem mobilności;

- autokratyczny styl zarządzania klasą niższą;

- potrzeba kulturowego importu modeli zachowań;

${ }^{43}$ J. Hryniewicz, op. cit., przyp. 3.

44 Osobną kwestią pozostaje pytanie o rolę kulturową folwarków. Pomimo ich zacofania gospodarczego w stosunku do Europy Zachodniej w Polsce pod zaborami pozostawały one nielicznymi instytucjami przekazującymi polską kulturę, język i wartości. W Wielkopolsce natomiast w XIX wieku folwarki stały się istotnymi ośrodkami modernizacyjnymi dla kultury rolnej, np. ośrodek w Turwi prowadzony przez Dezyderego Chłapowskiego.

${ }^{45}$ Ibidem. 
- odniesienie tego modelu do kultury religijnej: jest on charakterystyczny dla kultur katolickich.

Powyższe cechy powinny być określone właśnie jako „postfolwarczne”, gdyż są to kulturowe residua nieistniejących już instytucji życia gospodarczego. Takie residua kultury folwarcznej występowały już w PRL-u, który eksploatował model folwarczny: „W efekcie formalnych i nieformalnych regulacji socjalistyczne zakłady pracy były bardziej podobne do folwarków niż do typowych przedsiębiorstw kapitalistycznych. Życie codzienne koncentrowało się $\mathrm{w}$ grupach rodzinno-koleżeńskich, w których więź wzmacniana była samopomocą i wymianą świadczeń wymuszoną chronicznym deficytem socjalistycznego rynku"46. Przejście do gospodarki kapitalistycznej nie mogło się dokonać $\mathrm{w}$ pełni również ze względu na przeszkody kulturowe. Przejście to autor określa następująco: „Wyraźnym zmianom uległa struktura klasowo-warstwowa, pojawiła się klasa przedsiębiorców i zwiększyły się nieco różnice między klasami ludowymi a resztą społeczeństwa. Archetypy zachowań folwarcznych są nadal dobrze ugruntowane. Dopasowanie osobowości do modelu gospodarki rynkowej jest relatywnie słabe. [...] Identyfikacje strukturalne polegają na kluczowym znaczeniu grup rodzinno-koleżeńskich, sprzyja to wypaczaniu mechanizmów konkurencji rynkowej i demokratycznej rywalizacji politycznej"47. Prowadząc badania nad organizacją polskich przedsiębiorstw, autor skupił się między innymi na rolach kierowniczych. Spore znaczenie w polskiej kulturze gospodarczej odgrywa przywódca, wódz, „pan na folwarku”: „Ideałem kultury folwarcznej jest wódz o silnej osobowości. Jednakże siła osobowości jest tu rozumiana jako siła głosu i brak wahań w przydzielaniu ostrych, spektakularnych kar. [...] Towarzyszy temu zmienność emocjonalna i agresywne reakcje w sytuacjach trudnych" 48 . Badania autora pokazują, że najlepsi kierownicy wyemancypowali się $\mathrm{z}$ tej tradycyjnej kultury $\mathrm{w}$ stronę kultury realizacji celów, gdzie główną umiejętnością jest zarządzanie konfliktem oraz organizacja pracy grupy: "Zasadnicza różnica między wodzem a skutecznym przywódcą polega na tym, że wódz traktuje władzę jako przywilej braku umiaru $\mathrm{w}$ eksponowaniu własnych emocji. Czyni to z właściwą kulturze folwarcznej barokową wystawnością" ${ }^{49}$. Autor prezentuje również inne konteksty postfolwarcznej kultury w polskiej gospodarce. Jednym z jej przejawów jest bierność i oczekiwanie poleceń od przełożonego: „Z badań wyko-

\footnotetext{
46 Ibidem, s. 263.

47 Ibidem.

48 Ibidem, s. 338

49 Ibidem, s. 339.
} 
nanych w 2001 roku wynika, że 65\% pracowników wyraża zapotrzebowanie na ścisłe instrukcje ze strony przełożonego" ${ }^{50}$. Kolejnym są obce polskim instytucjom gospodarczym demokratyczne działania zarządcze, szczególnie wobec osób z niższego szczebla: "demokracja dla nas, dyktatura dla nich", ,[...] tendencja do przyjaznego traktowania członków klasy własnej - kierowniczej - i dystans oraz rezerwa wobec przedstawicieli klasy podporządkowanej" 51. Hryniewicz wskazuje na dualizm kultury organizacyjnej: innej, lepszej, dla „swoich” (tj. kolegów z własnej klasy społecznej), innej, "gorszej", dla podwładnych. Warto dodać, że w badaniach wskazano na wysokie koszty psychiczne pracowników udających się do pracy za granicą, wynikające $z$ nowych warunków pracy w odmiennej kulturze organizacyjnej.

Idąc za myślą autora, polski model kapitalizmu postfolwarcznego jest systemem tworzącym główny trzon uwarunkowań rodzimego państwa dobrobytu. Folwark przypomina „państwo opiekuńcze”, czy wręcz jest jego odcieniem. Przede wszystkim folwark oferował całościową opiekę nad pracownikiem. Otrzymywał on wsparcie poza pracą, w tym opiekę medyczną w czasie choroby, mógł też wprowadzać członków swojej rodziny do pracy na folwarku. Cechy te pokrywają się zresztą z innymi czynnikami kulturowymi, m.in. powiązanymi z religią. Hryniewicz, pisząc o typie wodza czy o emocjonalnym zaangażowaniu liderów instytucji gospodarczych, odzwierciedla schemat instytucjonalny: sprawy administracyjne, gospodarcze oraz obywatelskie w znacznej mierze zależą od charyzmy przywódcy, ale także od sieci nieformalnych powiązań. Przyjęte przez Hryniewicza uwarunkowania kulturowe objaśniają specyficzne polskie trudności w implementacji państwa dobrobytu. Kwestie takie jak civil rights stoją w sprzeczności z autokratycznym traktowaniem klas niższych. Podobnie jest ze „związkami krewniaczymi”, stojącymi w sprzeczności z ideałem powszechnego dostępu do dobrobytu, który odnosi się do postaw "obywatelstwa”, czyli szerszej całości. W swojej istocie kultura postfolwarczna nastawiona jest na spełnienie bezpieczeństwa socjalnego, co pokrywa się z typowym oczekiwaniem wobec państwa opiekuńczego. W tym sensie określony przez Hryniewicza model kulturowych uwarunkowań gospodarczych łączy elementy państwa opiekuńczego - jak poszukiwanie bezpieczeństwa socjalnego czy stabilizacja ekonomiczna - ze specyficzną dla Polski trajektorią rozwoju kulturowo-ekonomicznego.

\footnotetext{
50 Ibidem, s. 344.

51 Ibidem, s. 344-345.
} 


\section{KONTEKST POLSKI}

W jaki sposób można odnieść powyższy obraz do instytucji szkolnictwa wyższego? Podobnie jak $\mathrm{w}$ instytucjach gospodarczych, także $\mathrm{w}$ publicznych (w tym edukacyjnych) możemy odnaleźć analogie pomiędzy specyfiką postfolwarcznej kultury organizacyjnej a organizacją instytucji szkolnictwa wyższego i jego problemami.

Pierwsza analogia dotyczy problemu „swojskości” i ukierunkowania instytucji na znane i bezpieczne cele. Jest to powiązane $\mathrm{z}$ brakiem skłonności do ryzyka oraz konserwatywną postawą, zorientowaną na zachowanie status quo, charakterystyczną dla kultury folwarcznej. Wydaje się, że temu opisowi w jakimś stopniu może odpowiadać na polskich uczelniach niska mobilność oraz bardzo słaby przepływ kadr, szczególnie młodych uczonych, między ośrodkami, czy też mała internacjonalizacja ${ }^{52}$. W Polsce $\mathrm{w}$ bardzo niewielkim stopniu zatrudnia się adiunktów z zewnątrz, większość osób przyjmowanych do pracy pochodzi z tego samego ośrodka (zakładu, instytutu, wydziału), uczelni, miasta. Nowelizacja ustawy Prawo o szkolnictwie wyższym w 2012 roku spowodowała częściową blokadę nepotyzmu (przełożonym nie może być bliski krewny), jednakże nie wyzwoliła oczekiwanej mobilności uczonych ${ }^{53}$. Problemem staje się zależność doktoranta / młodego uczonego od promotora / szefa jednostki. W tym systemie występuje on w dwóch rolach: jako promotor naukowy, czyli osoba mająca dynamizować krytyczne myślenie, oraz potencjalny pracodawca. Role te mogą stać wobec siebie w sprzeczności, a ich niepożądanym efektem jest osłabienie krytyczności aplikanta oraz wywołanie mechanizmów tożsamości z grupą, jako ewentualnym przyszłym zespołem pracy. Sytuacja ta pokrywa się z charakterystyką Hryniewicza wskazującą dawanie pierwszeństwa relacjom grupowym (np. stosunkom dobrosąsiedzkim) przed działaniem konkurencyjnym. Na marginesie, potwierdza to treść polskiej debaty o mobilności. Warto zauważyć, że rzadko wysuwa się $\mathrm{w}$ niej argumenty dotyczące innowacyjności czy zwiększenia produktywności naukowej. Częściej stosuje się argumenty społeczne, np. dotyczące problemów z relokacją czy kosztami psychicznymi pojawiającymi się $\mathrm{w}$ przypadku zmiany miejsca pracy. Treść tych argumentów potwierdza priorytet racjonalności grupowo-krewniaczej.

52 Zob. C. Kościelniak, W jaki sposób filozofia publiczna może pomóc polskiemu szkolnictwu wyższemu? Rzecz o bolonizacji oraz internacjonalizacji, [w:] Edukacja demokratyczna, red. K. Cern, P. Juchacz, E. Nowak, seria Coopera, Wydawnictwo Naukowe Instytutu Filozofii UAM, Poznań 2009.

53 Zob. Ustawa z dnia 18 marca 2011 r. o zmianie ustawy - Prawo o szkolnictwie wyższym, ustawy o stopniach naukowych i tytule naukowym oraz o stopniach i tytule w zakresie sztuki oraz o zmianie niektórych innych ustaw, Dz.U. 2011 Nr 84, poz. 455. 
Autokratyczny styl kierowania jest kolejnym elementem polskiej nauki. Uczelnie w naszym kraju charakteryzują się formalną kulturą organizacyjną, dystansem między studentami a wykładowcami, ale także silną hierarchizacją środowiska. Ponownie, profesorowie czy adiunkci w swojej klasie (np. podczas konferencji czy spotkań towarzystw naukowych) zwykli stosować mniej formalną komunikację, traktując siebie jak „swoich”. Często katedry czy zakłady są zarządzane autokratycznie, a ich kierownicy nierzadko podkreślają feudalność swoich rządów. W odniesieniu do niższych klas w hierarchii akademickiej oraz studentów pozostają bardziej formalni. Wreszcie postawy wobec przedsiębiorczości i innowacyjności: polskie uczelnie nie kreują postaw przedsiębiorczości, lecz raczej nastawiają się na bierny odbiór w przypadku studentów jest to postawa „bycia zatrudnianym”. Najnowsze badania postaw studenckich w Polsce pokazują, że wśród studentów spada akceptacja dla ryzyka prowadzenia swojej działalności ${ }^{54}$. Większość polskich studentów chce być zatrudniana, oczekuje, że w przyszłej karierze będzie wykonywać polecenia innych. Warto jednak zauważyć, że polskie uczelnie rzadko uświadamiają sobie potrzebę kształcenia elit gospodarczych czy liderów zmiany. Studentów raczej nie przygotowuje się do ról przywódczych. Wydaje się wszakże, że system polski może przynieść pewne korzyści: w ośrodkach, gdzie panują "dobre praktyki”, model relacyjny, oparty na postfolwarcznej więzi emocjonalnej, może budować wartość dodaną - pozwala utożsamić się z uniwersytetem oraz z jego misją. Ponadto walorem autokratycznego zarządzania jest, przy założeniu wysokiej jakości merytorycznej, wpływ profesora na pracownika poprzez osobisty autorytet. Pozwala to także zbudować osobistą relację między nimi, często wskazaną w pracy intelektualnej. Nie jest też prawdą, że system atomistyczny, np. niemiecki, daje idealne efekty: widać wyraźnie, iż o ile najlepsze ośrodki badawcze znakomicie sobie z nim radzą, o tyle te średnie - a takich jest najwięcej - nie uzyskują efektów lepszych niż na przykład wiodące uczelnie w Polsce. Warto również brać pod uwagę raporty organizacji monitorujących, takich jak PKA czy Eurydice, gdzie polska sfera szkolnictwa wyższego ukazuje się jako rozwijająca się, reformująca i podnosząca swoją jakość.

Warto wskazać, że system folwarczny był autonomiczny w warunkach chronicznego niedofinansowania. Analogia z uczelniami jest tutaj wyraźna: system kultury organizacyjnej w znacznej mierze zależy od stanu finansowania, który od kilkunastu lat, z małymi wahaniami, pozostaje bez zmian.

${ }^{54} \mathrm{Na}$ kwestie te wskazują badania studium przypadków; zob. E. Piotrowska-Piątek, Badanie postaw studentów polskich $i$ stowackich wobec samozatrudnienia - komunikat $z$ badań, "E-Mentor” 2013, nr 5(52), s. 26-34, oraz coroczne raporty Komisji Europejskiej, np. z wykonania programu Erasmus. 
W tym kontekście możliwość zmiany zostaje ograniczona do aktywności aktorów wewnątrz instytucji. Staje się zrozumiałe, że liderzy sami muszą odnaleźć metody zwiększenia efektywności, natomiast taka samowystarczalność bliska jest modelowi folwarcznemu.

Na zakończenie warto zaznaczyć, że oczekiwanie wobec państwa, iż stanie się "państwem dobrobytu” na wzór tych z lat osiemdziesiątych na Zachodzie, powoli odchodzi. W edukacji dowodzi tego coraz większe nasilenie zjawiska klasowości i ukrytej „prywatyzacji” - rozumianej jako finansowanie przez rodziców edukacji dzieci. Widać to wyraźnie na poziomie edukacji średniej: uczniami prywatnych szkół są dzieci dobrze sytuowanej, niewielkiej klasy średniej. Do szkół publicznych uczęszczają najczęściej dzieci $\mathrm{z}$ rodzin będących $\mathrm{w}$ klasie niższej. Rosnąca dyferencjacja $\mathrm{w}$ systemie edukacji rodzi pytanie o powstanie w przyszłości społeczeństwa klasowego, z segregacją ekonomiczną i coraz węższym awansem społecznym, ze względu na coraz droższe i niedostępne instrumentarium edukacyjne niezbędne do tego awansu. Ponownie można powtórzyć użyty już argument: brak środków ekonomicznych doprowadza do dysfunkcji społecznej, ale i do paradoksów. Beneficjentami bezpłatnych studiów na najbardziej obleganych kierunkach są zarówno najlepsi, jak i najlepiej uposażeni, którzy polityki równości nie potrzebują. W systemie giną „,średni”, których instrumentarium państwa opiekuńczego już nie obejmuje. Zjawisko to będzie decydowało o przyszłości edukacji wyższej, ale także będzie znaczącym czynnikiem wpływającym na zmianę struktur organizacyjnych instytucji wiedzy. Powyższe kwestie zostały jedynie wstępnie zarysowane i wymagają dalszych zaawansowanych analiz. Celem było ukazanie polskiego kontekstu instytucji wiedzy na tle przemian państwa dobrobytu. Zaangażowanie koncepcji kultury postfolwarcznej wydaje się narzędziem do wydajnego osiągnięcia wyników poznawczych.

W obecnym kryzysie państwa dobrobytu kulturowy i ekonomiczny kontekst rozwoju uniwersytetu zostaje poddany próbie. O ile społeczeństwa państw Unii Europejskiej przeciwstawiają się polityce cięć, o tyle Realpolitik nie pozostawia złudzeń: finansowanie europejskich uczelni na dawnym poziomie, a w przyszłości utrzymanie tak szerokiego do nich dostępu staje się mission impossible. Zachowanie tradycyjnych zobowiązań i celów, takich jak np. poszerzanie dostępu oraz funkcji partycypacyjnych uniwersytetu, jest wyzwaniem, któremu coraz trudniej jest sprostać. Problemy te mają wymiar wielopoziomowy, a wynikają z kryzysu gospodarczego, demograficznego i kulturowego. Złożoność tej sytuacji została omówiona w niniejszym artykule. Projektowanie wszelkich zmian na wzór rozwiązań welfare state, czy to na poziomie projektów ideowych, czy policy papers, nie może 
pomijać nierównej dynamiki zmiany kulturowej: modernizacja nie opiera się tylko na sferze finansowej, ale także na przemianie normatywnej, obyczajowej i organizacyjnej. Widać to wyraźnie na pokazanym powyżej przykładzie Polski. Zmiana ról uniwersytetu płynąca z transformacji państwa dobrobytu dotyka nie tylko sfery instytucjonalnej, lecz także społecznie ugruntowanego poczucia uprawnień oraz kulturowej wizji uniwersytetu. Współfinansowany ze środków publicznych dostęp do instytucji wiedzy oraz traktowanie uczelni jako bramy do dobrobytu są mocno ugruntowane w społeczeństwach Europy (co pokazują chociażby protesty studenckie w różnych krajach). Kryzys ekonomiczny powoduje presję zmiany ról uczelni: wymaga się od nich zbliżenia z rynkiem pracy, współudziału w dynamizowaniu lokalnych gospodarek oraz kształcenia łatwo aplikowanego do aktualnych potrzeb. Obecnie trudno przewidzieć, jaki model uczelni wyłoni się w przyszłości; można $\mathrm{z}$ pewnym ryzykiem postawić tezę, że zmiany idą $\mathrm{w}$ kierunku powstania zatomizowanych, wyspecjalizowanych i działających na modłę przedsiębiorstw instytucji łączących badania naukowe ze specjalistycznym kształceniem generowanym przez potrzeby rynku. Jest również prawdopodobne, że w długotrwałym kryzysie pojawi się tendencja do poszerzania modelu odpłatności za kształcenie. Tym samym model „edukacji dobrobytu” $\mathrm{w}$ Unii będzie ewoluował $\mathrm{w}$ stronę modelu mieszanego, $\mathrm{z}$ rosnącym udziałem kontrybucji finansowej po stronie obywateli.

\section{BIBLIOGRAFIA}

Abbas A., Kolejna rewolucja w angielskim szkolnictwie wyższym?, [w:] Wolność, równość, uniwersytet, red. C. Kościelniak, J. Makowski, Instytut Obywatelski, Warszawa 2011.

Bell D., Kulturowe sprzeczności kapitalizmu, przeł. S. Amsterdamski, Wydawnictwo Naukowe PWN, Warszawa.

Berger P., Rewolucja kapitalistyczna, przeł. Z. Simbierowicz, Oficyna Naukowa, Warszawa 1995.

Busemeyer M., Nikolai R., Education, [w:] Oxford Handbook of Welfare State, eds F.G. Castles et al., Oxford University Press, Oxford 2010.

Castells M., Himanen P., Społeczeństwo informacyjne i państwo dobrobytu, przeł. M. Penkala, Wydawnictwo „Krytyki Politycznej”, Warszawa 2009.

Clark B., Creating Entrepreneurial University, Pergamon, Oxford 1998.

Culture and Welfare State, eds W. Oorschot, M. Opielka, B. Pfau-Effinger, Edward Elgar Publishing, Northampton 2008.

Dylus A., Globalizacja. Refleksje etyczne, Ossolineum, Wrocław 2005.

Education at Glance, OECD, Paris 2011.

Entrepreneurship, Innovation, and Economic Development, eds A. Szirmai et al., Oxford University Press, Oxford 2011. 
Esping-Andersen G., Trzy światy kapitalistycznego państwa dobrobytu, przeł. K. Frieske, Difin, Warszawa 2010.

Eurydice: http://eacea.ec.europa.eu/education/eurydice/about_eurydice_en.php [dostęp: 31.01.2014].

Gal Z., Ptacek P., The Role of Mid-Range Universities in Knowledge Transfer in NonMetropolitan Regions in Central Eastern Europe, „European Planning Studies” 2011, vol. 19, iss. 9.

Galbraith K., Ekonomia a cele społeczne, przeł. W. Osiatyński, PWN, Warszawa 1979.

y Gasset O., Mission of the University, Princeton University Press, Princeton 2009.

Goastellec G., Wolność dostępu do uniwersytetów. Gwarancja nierówności?, [w:] Wolność, równość, uniwersytet, red. C. Kościelniak, J. Makowski, Instytut Obywatelski, Warszawa 2011.

Gough I., Therborn G., The Global Future of Welfare States, [w:] Oxford Handbook of Welfare State, eds F.G. Castles et al., Oxford University Press, Oxford 2010.

Habermas J., Kryzys państwa dobrobytu $i$ wyczerpanie się energii utopijnych, przeł. P. Sztompka, "Colloquia Communia” 1986, nr 27.

Hofstede G., Cultures and Organizations, Profile Books, London 2003.

Hryniewicz J., Polityczny $i$ kulturowy kontekst rozwoju gospodarczego, Wydawnictwo Naukowe Scholar, Warszawa 2004.

Huntington S., Zderzenie cywilizacji $i$ nowy kształt ładu światowego, przeł. H. Jankowska, MUZA SA, Warszawa 2000.

Keating M., Culture in Social Science, [w:] Approaches and Methodologies in Social Science, eds D. della Porta, M. Keating, Cambridge University Press, Cambridge 2003.

Kerr C., The Uses of the University, Harvard University Press, Cambridge, MA 2001.

Kościelniak C., Polityka szkolnictwa wyższego w Unii Europejskiej, [w:] Polityka Unii Europejskiej, red. E. Małuszyńska (w druku).

Kościelniak C., The Context of the "Third Mission" in the "Peripherial Universities". A Case Study of the "Cross-border" University, [w:] Thinking about Provincialism in Thinking, eds K. Brzechczyn, K. Paprzycka, „Poznan Studies in the Philosophy of Science and the Humanities" 2012, vol. 100, Rodopi, Amsterdam-New York.

Kościelniak C., Unijne wyzwania polskiego szkolnictwa wyższego, [w:] Polska w Unii Europejskiej. Bilans dekady, red. F. Tereszkiewicz, Kancelaria Prezydenta, Warszawa 2013.

Kościelniak C., Uniwersytet $i$ aktywizm studencki wobec obywatelskiego niepostuszeństwa, [w:] Wolność, równość, uniwersytet, red. C. Kościelniak, J. Makowski, Instytut Obywatelski, Warszawa 2011.

Kościelniak C., W jaki sposób filozofia publiczna może pomóc polskiemu szkolnictwu wyższemu? Rzecz o bolonizacji oraz internacjonalizacji, [w:] Edukacja demokratyczna, red. K. Cern, P. Juchacz, E. Nowak, seria Coopera, Wydawnictwo Naukowe Instytutu Filozofii UAM, Poznań 2009.

Kościelniak C., Roemer R., Sustainable Development as a Part of the "Third Mission" of the Universities, „Safety of Technogenic Environment” 2013, no. 4, Riga.

Kwiek M., Accessibility and Equity, Market Forces and Entrepreneurship: Developments in Higher Education in Central and Eastern Europe, "Journal of the Programme on Institutional Management in Higher Education" 2008, vol. 20, OECD, Paris.

Kwiek M., The University and the Welfare State in Transition. Changing Public Services in Wider Context, [w:] World Yearbook of Education 2008. Geographies of Knowledge, Geometries of Power: Framing the Future of Higher Education, eds D. Epstein et al., Routledge, New York 2007. 
Kwiek M., Transformacje uniwersytetu, Wydawnictwo Naukowe UAM, Poznań 2010.

Magnier A., W poszukiwaniu włoskiej polityki szkolnictwa wyższego, [w:] Wolność, równość, uniwersytet, red. C. Kościelniak, J. Makowski, Instytut Obywatelski, Warszawa 2011.

Mariel M., Lemonik A., Student Activism and Curricular Change in Higher Education, Ashgate Publishing, Farnham 2011.

Newman J.H., Idea uniwersytetu, przeł. P. Mroczkowski, PWN, Warszawa 1990.

Nussbaum M., Cultivating Humanity, Harvard University Press, Cambridge, MA 2007.

Nussbaum M., Not for Profit. Why Democracy Needs The Humanities, Princeton University Press, Princeton 2012.

Olechnicka A., Potencjał nauki a innowacyjność regionów, Wydawnictwo Naukowe Scholar, Warszawa 2012.

Oxford Handbook of Welfare State, eds F.G. Castles et al., Oxford University Press, Oxford 2010.

Pavel P., Breakthrough Communities, MIT Press, Cambridge, MA 2009.

Pierwsze kroki na rynku pracy. Międzynarodowe badania absolwentów, raport firmy Deloitte, Warszawa 2013.

Piotrowska-Piątek E., Badanie postaw studentów polskich i stowackich wobec samozatrudnienia komunikat $z$ badań, „E-Mentor" 2013, nr 5(52).

Poland. Tertiary Education, OECD, Paris 2007.

Prestiz wśród pracodawców, ranking pracodawców magazynu "Perspektywy”, http://www.perspektywy.pl/portal/index.php?option=com_content\&view=article \&id=713:prestiz-pracodawcow\&catid=90\&Itemid=230 [dostęp: 17.09.2014].

Scholz R., Environmental Literacy in Science and Society, Cambridge University Press, Cambridge 2012.

Sen A., Wolność jako rozwój, przeł. J. Łoziński, Zysk i S-ka Wydawnictwo, Poznań 1998.

Sławek T., Autonomia, dtug, ksztatcenie, [w:] Wolność, równość, uniwersytet, red. C. Kościelniak, J. Makowski, Instytut Obywatelski, Warszawa 2011.

Sławek T., Autonomia, integralność, uniwersytet, „Anthropos” 2012, vol. 18/19.

Statystyki konkursów, raport NCN, Kraków 2013.

Szirmai A., The Dynamics of Socio-Economics Developments, Cambridge University Press, Cambridge 2006.

Szweda-Lewandowska Z., Procesy ludnościowe w Polsce - następstwa przystapienia do Unii Europejskiej, [w:] Polska w Unii Europejskiej. Bilans dekady, red. F. Tereszkiewicz, Kancelaria Prezydenta, Warszawa 2013.

Toivanen O., Innovation Policy, Entrepreneurship and Development: A Finnish View, [w:] Entrepreneurship, Innovation, and Economic Development, eds A. Szirmai et al., Oxford University Press, Oxford 2011.

Twardowski K., O dostojeństwie uniwersytetu, reprint z 1931 roku, Wydawnictwo Naukowe UAM, Poznań 2011.

Wojciechowski S., Instytucje kultury w Polsce na tle przemian kultury w latach 1989-2009. Globalizm, lokalność, kryzys, [w:] Instytucje kultury w czasach kryzysu, red. P. Kieliszewski i in., Bogucki Wydawnictwo Naukowe, Poznań 2009.

Wolność, równość, uniwersytet, red. C. Kościelniak, J. Makowski, Instytut Obywatelski, Warszawa 2011.

World in Transition: Sustainability Perspectives for Higher Education, eds M. Adomssent, A. Beringer, M. Barth, VAS Verlag, Frankfurt 2013. 